\title{
Grup İçi Korelasyon Katsayısının Örnekleme Dağılımı
}

\author{
Ensar BASSPINAR \\ Fikret GORBÜZi
}

Geliş Tarihi: 20.09.1999

\begin{abstract}
Özet: Bu çalışmada, grup içi korelasyon katsayısının örnekleme dağılımının belirlenmesi amaçlanmıştır. Bunun için, simülasyon tekniğinden yararlanılarak, 100000 simülasyon denemesi sonunda, çeșitli grup arasi korelasyon yapısındaki populasyonlardan rasgele alınan değișik grup sayısı ve örnek genişliğindeki örneklerde hesaplanan grup içi korelasyon katsayılarının dağılımları elde edilmiştir. Sonuç olarak, grup içi korelasyon katsayısının normal dağımadığı belirlenmiştir.
\end{abstract}

Anahtar Kelimeier: Grup arası korelasyon, grup içi korelasyon, tekrarlanma derecesi, örnekleme dağılımı

\section{The Sampling Distribution of Intra-Class Correlation Coefficient}

\begin{abstract}
The determination of the sampling distribution of intra-class correlation coefficient was purposed in this study. For this, the simulation technique was used. The intra-class correlation coefficients were calculated at the end of the one hundred thousand simulation experiments and then the shape of the distribution of these values was looked. These distributions were obtained the samples taken randomly from the populations, which have the various inter-class correlation structures and the different number of groups and sample sizes. Consequently, it was seen that the intraclass correlation coefficient was non-normal distributed.
\end{abstract}

Key Words; Inter-class correlation, intra-class correlation, repeatability, sampling distributions

\section{Giriş}

Grup içi korelasyon katsayısı, özellikle islah çalışmalarında, genetik bir parametre olan kalıtım derecesinin tahmin edilmesinde kullanilan bir istatistiktir (Turner ve Young 1969). Bu istatistik, ayni zamanda tekrarlanan ölçümlù denemelerde ölçümlerin güvenilirliğini (reliability) ifade etmede de kullanilmaktadır (Winer 1971).

Grup içi korelasyon katsayısının örnekleme dağılımi, her hangi bir örnekte hesaplanan grup içi korelasyon katsayısının istatistik olarak önemli olup olmadığının hipotez testinin yapılmasında önemlidir.

Bu çalışmada, grup içi korelasyon katsayısının örnekleme dağılıminin, çeşitli grup arası (inter-class) korelasyon katsayısına sahip populasyonlardan rasgele olarak alınan değişik grup ve deney ünitesi sayısına göre simülasyon tekniği kullanilarak belirlenmesi amaçlanmıştır.

\section{Materyal ve Yöntem}

Çalıșma materyalini, Microsoft Power Station Developer Studio'nun IMSL Library'sinden yararlanilarak ûretilen tesadüf sayıları olușturmuştur. Oretilen tesadüf sayıları dört farklı yapıda populasyondan elde edilmiştir. Bu populasyonlar;

i. Tesadüf sayılari aralarında $\rho=0,00$, ii. $\rho=0.30$ (düşük), iii. $\rho=0.60$ (orta) ve iv. $\rho=0.90$ (yüksek) grup arası (inter-class) korelasyon olacak şekilde uretilmişlerdir.
Daha sonra populasyonların her birinden değisșik grup $(k \mid=2,5,10$ ve $15,45,90)$ ve her bir grupta da değişik deney ünitesi ( $n=2,6,10,25$ ve $2,4,6,25)$ bulunan örnekler rasgele olarak alınmıştır (Çizelge 1). 2,5,10 grup sayısını içeren veriler, grup sayısına göre "Küçük", 15,45,90 grup sayısını içeren veriler de "Büyük" olarak tanımlanmıştır. Bu örneklerde varyans analizi yapilip, kareler ortalamalarının beklenen değerlerinden yararlanilarak, grup içi korelasyon katsayısı hesaplanmıştır. Bu işlem her örnek için 100000 defa tekrarlanıp, çeşitli grup arası korelasyon-grup-örnek genişliḡi kombinasyonları için grup içi korelasyon katsayısının dağılımları ampirik olarak elde edilmiştir.

Çalışmada gerekli olan bütủn hesaplama ve veri üretiminde, FORTRAN programlama dilinde yazilan programlardan, grafiklerin çiziminde ise "STATISTICA for Windows" istatistik paket programından yararlanılmıştır.

Çizelge 1. Çalışmada kullanilan örnek genişlikleri.

\begin{tabular}{|c|c|c|c|c|c|}
\hline \multicolumn{4}{|c|}{ Grup sayısı $\left(k_{i}\right)$} & \multicolumn{5}{c|}{ Grup arasi korelasyonlar $\left(p_{i}\right)$} \\
\hline \multicolumn{2}{|c|}{} & \multicolumn{4}{|c|}{$p_{i}=0.00,0.30,0.60,0.90$} \\
\hline Küçük & 2 & 2 & 6 & 10 & 25 \\
\hline & 5 & 2 & 6 & 10 & 25 \\
\hline & 10 & 2 & 6 & 10 & 25 \\
\hline Büyäk & 15 & 2 & 4 & 6 & 25 \\
\hline & 45 & 2 & 4 & 6 & 25 \\
\hline & 90 & 2 & 4 & 6 & 25 \\
\hline
\end{tabular}

\footnotetext{
1 Ankara Üniv, Ziraat Fak. Zootekni Bölümú Biyometri ve Genetik Anabilim Dali-Ankara
} 
Grup içi korelasyon katsaylianinin hesaplanmasında (Fisher 1958, Turner ve Young 1969, Winer 1971, Sokal ve Rohif 1995)'da bildirilen tek yônlü varyans analizi tekniği sonunda, kareler ortalamalarının beklenen unsuiları hesaplanip, bunlar yardımıyia $c=\sigma_{\text {ara }}^{2} /\left(\sigma_{\text {ara }}^{2}+n_{\text {ig }}^{2}\right)$ eşitliği kullanılmıştır. Bunun için;

\begin{tabular}{cc} 
Grup & $x_{i j}$ \\
\hline 1 & $\begin{array}{c}x_{11}, \\
x_{21}, x_{22}, x_{1 j} \\
x_{2 j}\end{array}$ \\
$k$ & $x_{k 1}, x_{k 2} \ldots x_{k j}$
\end{tabular}

gözlem değerieri kullanılarak varyans analizi sonunda .

$$
\begin{aligned}
& E(\text { Gruplar Arası Kareler Ortalamasi })={ }_{\pi \text { if }}^{2}+n \sigma_{\text {ara }}^{2} \\
& E \text { (Grup Içi Kareler Ortalamasi })=\left.{ }_{\square}\right|_{i \zeta \zeta} ^{2}
\end{aligned}
$$
eşitlikleri kullanilarak $\sigma_{\text {ara }}^{2}$ bulunmuştur. Bu değerin $\left(\sigma_{\text {ara }}^{2}+\sigma_{\text {iç }}^{2}\right)^{\prime}$ 'e bölünmesiyle de grup içi korelasyon katsayısı (tekrarlanma derecesi=r) hesaplanmıștur. Bunun asimtotik olarak beklenen deḡeri populasyondaki gözlemler arasında oluşturulan gruplar arası korelasyon (p) katsayısına eșittir (Winer 1971, Rosner 1979, Düzgüneş ve ark. 1987). Bu şekilde 100000 simülasyon sonunda hesaplanan tekrarlanma derecelerinin tanımlayıcı istatistikleri hesaplanmiş ve histogramları çizilerek her grup arası korelasyon-grup sayısı-örnek genişliği kombinasyonu için dağilım şekilleri a npirik olarak elde edilmiştir,

\section{Bulgular ve Tartişma}

Çalışmada 100000 simülasyon denernesi sonunda hesaplanan grup içi korelasyon katsayiları ın tanimlayıcı istatistikleri, Çizelge 2'de, histogramlan da 'jekil 1, Şekil 2. Şekil 3 ve Şekil 4 te populasyonlarin grup a rası korelasyon yapilarına, grup sayısına ve her gruptaki sözlem sayısına göre topluca verilmiştir.

Çizelge 2'nin pij=0.00 kısm ile \& ekil $\jmath^{\prime}$ in birlikte incelenmesi ile, grup sayisinın 2 ve her gruptaki gözlem sayisi da ne olursa olsun hesaplanan g up içi korelasyon katsayısının $[-1,+1]$ aralığında değer al liğını ve bunların negatif olanlarınin da daima poziti olanlardan çok (\%51'den çok) olduğu görülmektedir. Halbuki, grup içi korelasyon katsayisinin negatif olm sinın bir anlamı yoktur. 100000 simülasyon sonunda elde edilen grup içi korelasyon katsayılarının gösterdiği dağılımın da normal dağılım olmadiğı görülmektedir.

Grup sayısınin artinimasi yuharidaki genel eğilimleri etkilememekte, ancak grup içi korejasyon katsayısının daḡılımının nispeten simetrikleşmesine sebep olmaktadır. Mesela grup sayısı 90 ve her grupta da 2 deney unitesi bulunursa, grup içi korelasyon katsayısının ornekleme dağılımının eğiklik katsayısı sıfıra yaklaşmakta (bu durum simetriklik içín önemlidir), fakat hesaplanan grup içi korelasyon katsayılarının yine yaklaşık yarısı negatif deḡer almaktadır.

Çizelge 2'nin pij $=0.30$ kısmı ile Şekil 2'nin birlikte incelenmesi ile, grup sayısının ve her gruptaki gözlem sayısinin $k_{i}=2$ ve $n_{i}=2^{\prime}$ den itibaren artirilmasina paralel olarak hesaplanan grup içi korelasyon katsayısı da $[-1,+1]$ aralığından itibaren [0.15,0.46] araiığina kadar değer aldığını ve bunların negatif olanlarinin da gruplardaki gózlem sayısına bağlı olarak yaklașık $\% 40$ ila $\% 0$ arasında oldukları görülmektedir. 100000 simülasyon sonunda elde edilen grup içi korelasyon katsayılarinin gösterdiği dağllimin da şekil olarak oldukça değişken bir durum gösterdiği görülmektedir. Grup sayısının artırılması, hesaplanan grup içi korelasyon katsayısınin p'ya yaklașmasıni sağlamakta ancak bu durum gruplardaki gözlem sayısından fazla etkilenmemektedir. Grup içi korelasyon katsayısınin örnekleme dağilımının çok değişken bir yapı göstermesi dikkat çekicidir. Bu dağılımın normal dağılım göstermesinin asimtotik olarak blle gerçekleșemeyeceği eğilimi, eğiklik ve diklik katsayılarının seyri göz önüne alındığında görüimektedir. Hesaplanan grup içi korelasyon katsayllarinin tamamının pozitif (anlamli) olması için, grup sayısınin en az 45 ve her gruptaki gózlem sayısının da 4 olmasi gerektiği Çizelge 2'nin incelenmesiyle anlaşılmaktadır.

Çizelge 2'nin pij=0.60 kısmı lie Şekil 3'ün birlikte incelenmesi ile, grup sayısının 10'dan az olması halinde, gruplardaki gözlern sayılarına göre değișen oranlarda, hesaplanan grup içi korelasyon katsayılarının arasında negatif deḡerlere rastlanılabileceği görülmektedir. Grup sayısının 10-15 olması halinde de negatif değerli grup içi korelasyonla karşılaşmamak için, her grupta 2 den fazla gözlem değeri gereklidir. $p=0.60$ olduğu populasyondan rasgele alınan örnekierde 100000 simülasyon sonunda elde edilen grup içi korelasyon katsayılarının gösterdiği dag̀lımın, şekil olarak çok değişkenlik göstermesi $p=0,30$ olan populasyon için hesaplanan grup içi korelasyonlarin dağılım şekillerinden daha belirgindir. Grup sayısınin 45 ve dahs fazla olmasıyla, her gruptaki gözlem sayısına baǵlı olarak, grup içi korelasyon katsayısının örnekieme dağılımının da gittikçe simetrikleştiği izlenimi Şekil 3'ten edinilmektedir. Ancak, ömekieme dağlımının normal dağilım gostermesinin de asimtotik olarak sağlanabileceğinin ileri sürülmesi, Çizelge 2'nin incelenmesinden anlaşılacağı gibi oldukça zordur. $p=0.60$ olan bir populasyondan rasgele alınan örneklerden hesaplanan grup içi korelasyon katsayısi, grup sayisi 45 ve daha fazla ve her gruptaki gözlem sayısı da en a2 2 olması halinde anlamli değerier almaktadir. Cünkü, bu durumda grup içi korelasyon katsayısı ortalama olarak piya yaklaşmakta ve pozitif değerler almaktadır. 
BASPPINAR, E. ve F, GÜRUUZ "Grup içi koreiasyon katsayisının ömekleme dağılımi"

Çizelge 2. 100000 Simülasyon denemesi sonunda hesaplanan grup içi korelasyon katsayılarının tanımlayıcı istatistikleri

\begin{tabular}{|c|c|c|c|c|c|c|c|c|c|}
\hline$\rho_{1}$ & Grup & $n_{i l}$ & Ortalama & Minimum & Maksimum & $\begin{array}{l}\text { Standart } \\
\text { sapma. }\end{array}$ & $\begin{array}{c}\text { Eğiklik } \\
\text { katsayısı }\end{array}$ & $\begin{array}{c}\text { Diklik } \\
\text { katsayısı }\end{array}$ & $\begin{array}{c}\text { Negatlf } t \\
\text { yüzdesi }(\%)\end{array}$ \\
\hline \multirow[t]{24}{*}{0.00} & 2 & 2 & -0.1392 & -1.0000 & 1.0000 & 0.6428 & 0.2007 & $-1,3363$ & 57.5 \\
\hline & & 6 & -0.0211 & $-0,2000$ & 0.9142 & 0.1961 & 1.3990 & 1.5123 & 66.2 \\
\hline & & 10 & -0.0079 & -0.1111 & 0.8266 & 0.1232 & 1.7735 & 3.3878 & 67.0 \\
\hline & & 25 & -0.0015 & -0.0417 & 0.5054 & 0.0527 & 2.2736 & 6.7232 & 67.9 \\
\hline & 5 & 2 & -0.0197 & $-0,9954$ & 0.9807 & 0.4280 & -0.0165 & -0.8014 & -51.2 \\
\hline & & 6 & -0.0211 & -0.2000 & 0.9142 & 0.1961 & 1.3990 & 1.5123 & 574 \\
\hline & & 10 & -0.0010 & -0.1108 & 0.4394 & 0.0710 & 1.0645 & 1.2929 & 58.3 \\
\hline & & 25 & $-0,0002$ & -0.0416 & 0.2519 & 0.0283 & 1.2756 & 2.3035 & 59.0 \\
\hline & 10 & 2 & -0.0041 & -0.9417 & 0.9021 & 0.3086 & -0.0120 & -0.4962 & 50.5 \\
\hline & & 6 & -0.0003 & -0.1909 & 0.4496 & 0.0840 & 0.6432 & 0.4063 & 54.6 \\
\hline & & 10 & -0.0003 & $-0,1067$ & 0.3005 & 0.0488 & 0.7505 & 0.6618 & 55.6 \\
\hline & & 25 & 0.0000 & -0.0390 & 0.1292 & 0.0191 & 0.8597 & 1.0119 & 56.0 \\
\hline & 15 & 2 & $-0,0016$ & -0.8456 & 0.8564 & 0.2529 & -0.0225 & -0.3353 & 50.0 \\
\hline & & 4 & -0.0002 & -0.2853 & 0.5178 & 0.1063 & 0.4019 & 0.0271 & 52.9 \\
\hline & & 6 & -0.0001 & -0.1759 & 0.3960 & 0.0678 & 0.5258 & 0.2965 & 53.6 \\
\hline & & 25 & 0.0000 & -0.0386 & 0.1024 & 0.0154 & 0.7039 & 0.7180 & 54.8 \\
\hline & 45 & 2 & -0.0006 & -0.6294 & 0.6094 & 0.1480 & -0.0029 & -0.1329 & 50.1 \\
\hline & & 4 & 0.0001 & -0.2131 & 0.2767 & 0.0609 & 0.2358 & 0.0180 & 51.5 \\
\hline & & 6 & 0.0000 & -0.1201 & 0.1846 & 0,0386 & 0.3006 & 0.0768 & 51.9 \\
\hline & & 25 & 0.0000 & -0.0286 & 0.0494 & 0.0087 & 0.3973 & 0.2313 & 52.6 \\
\hline & 90 & 2 & -0.0004 & -0.4006 & 0.4688 & 0.1052 & 0.0013 & $-0,0736$ & 50.2 \\
\hline & & 4 & 0.0002 & -0.1669 & 0.2240 & 0.0430 & 0.1627 & -0.0092 & 50.9 \\
\hline & & 6 & -0.0001 & -0.0958 & 0.1353 & 0.0273 & 0.2195 & 0.0504 & 51.6 \\
\hline & & 25 & 0.0000 & -0.0227 & 0.0296 & 0,0061 & 0.2756 & 0.0875 & 51.9 \\
\hline \multirow[t]{24}{*}{0.30} & 2 & 2 & 0.0386 & -0.9999 & 1.0000 & 0.6629 & -0.1643 & $-1,3948$ & 460 \\
\hline & & 6 & 0.1718 & -0.2000 & 0.9779 & 0.3099 & 0.5172 & -0.9350 & 39.4 \\
\hline & & 10 & 0.1925 & -0.1111 & 0.9486 & 0.2639 & 0.6400 & -0.7261 & 33.3 \\
\hline & & 25 & 0.2090 & $-0,0417$ & 0.9128 & 0.2267 & 0.7534 & -0.4970 & 23.2 \\
\hline & 5 & 2 & 0.2268 & -0.9899 & 0.9966 & 0.4138 & -0.4886 & -0.4743 & 28.5 \\
\hline & & 6 & 0,2605 & -0.1978 & 0.8944 & 0.2015 & 0.0826 & -0.6512 & 10.9 \\
\hline & & 10 & 0.2653 & -0.1100 & 0,8335 & 0.1729 & 0,1719 & -0.6176 & 5.8 \\
\hline & & 25 & 0.2696 & -0.0406 & 0.7957 & 0.1478 & 0.2505 & -0.5386 & 1.4 \\
\hline & 10 & 2 & 0.2685 & -0.8776 & 0.9582 & 0.2903 & -0.4572 & -0.1516 & 18.3 \\
\hline & & 6 & 0.2805 & -0.1579 & 0.7842 & 0.1434 & -0.0067 & $-0,3622$ & 2.3 \\
\hline & & 10 & 0.2839 & -0.0969 & 0.7447 & 0.1224 & 0.0626 & -0.3674 & 0.5 \\
\hline & & 25 & 0,2858 & -0.0308 & 0.6903 & 0.1050 & 0.1145 & -0.3350 & 00 \\
\hline & 15 & 2 & 0.2806 & -0.6820 & 0.9261 & 0.2359 & -0.4063 & $-0,0633$ & 12.6 \\
\hline & & 4 & 0.2857 & -0.2565 & 0,7750 & 0.1403 & -0.0978 & -0.2428 & 2.3 \\
\hline & & 6 & 0.2877 & -0.1207 & 0.7547 & 0.1173 & -0.0198 & $-0,2471$ & 0.6 \\
\hline & & 25 & 0.2907 & 0.0124 & 0.6299 & 0.0854 & 0.0857 & -0.2223 & 0.0 \\
\hline & 45 & 2 & 0.2939 & -0.3653 & 0.7536 & 0.1356 & -0.2541 & -0.0079 & 2.1 \\
\hline & & 4 & 0.2956 & -0.0529 & 0.6002 & 0.0813 & -0.0774 & -0.1100 & 0.0 \\
\hline & & 6 & 0.2961 & 0.0144 & 0.5613 & 0.0672 & -0.0311 & -0.1075 & 0.0 \\
\hline & & 25 & 0.2968 & 0.0934 & 0.5172 & 0.0494 & 0.0324 & -0.0837 & 0.0 \\
\hline & 90 & 2 & 0.2971 & -0.1687 & 0.6505 & 0.0959 & -0.1803 & 0,0080 & 0.2 \\
\hline & & 4 & 0.2981 & 0.0621 & 0.5339 & 0.0572 & -0.0592 & -0.0501 & 0.0 \\
\hline & & 6 & 0.2981 & 0,1002 & 0.4982 & 0.0479 & -0.0237 & -0.0716 & 0.0 \\
\hline & & 25 & 0.2983 & 0.1534 & 0.4555 & 0.0351 & 0.0239 & -0.0550 & 0.0 \\
\hline
\end{tabular}


Çizelge 2. (Devami) 100000 Simülasyon denemesi sonunda hesaplanan grup içi korelasyon katsayılanının tanımlayıcı istatistikleri

\begin{tabular}{|c|c|c|c|c|c|c|c|c|c|}
\hline$p_{i}$ & Grup & $n_{i i}$ & Ortalama & Minimum & Maksimum & $\begin{array}{l}\text { Standart } \\
\text { sapma. }\end{array}$ & $\begin{array}{c}\text { Eğiklik } \\
\text { katsayısı }\end{array}$ & $\begin{array}{c}\text { Diklik } \\
\text { katsayisı }\end{array}$ & $\begin{array}{c}\text { Negatif r } \\
\text { yüzdesi }(\%)\end{array}$ \\
\hline \multirow[t]{24}{*}{0.60} & 2 & 2 & 0.2465 & -0.9999 & 1.0000 & 0.6547 & -0.6110 & -1.0387 & 33.2 \\
\hline & & 6 & 0.3636 & -0.2000 & 0.9892 & 0.3664 & -0.0966 & -1.3618 & 24.1 \\
\hline & & 10 & 0.3838 & -0.1111 & 0.9873 & 0.3319 & -0.0265 & -1.3619 & -19.4 \\
\hline & & 25 & 0.3973 & -0.0417 & 0.9819 & 0.3035 & 0.0504 & -1.3506 & 128 \\
\hline & 5 & 2 & 0.5003 & -0.9877 & 0.9979 & 0.3526 & -1.1547 & 1.0964 & 10.1 \\
\hline & & 6 & 0.5251 & -0.1972 & 0,9618 & 0.2158 & -0.6757 & -0.0762 & 1.9 \\
\hline & & 10 & 0.5277 & -0.1071 & 0.9382 & 0.1977 & $-0,5895$ & -0.2198 & 0.7 \\
\hline & & 25 & 0.5322 & -0.0409 & 0,9256 & 0.1829 & -0.5455 & -0.2883 & 0.2 \\
\hline & 10 & 2 & 0.5564 & -0.7037 & 0.9831 & 0.2272 & -1.0183 & 1.2390 & 2.5 \\
\hline & & 6 & 0.5653 & -0.1199 & 0.9377 & 0.1437 & -0.6627 & 0.3372 & 0.0 \\
\hline & & 10 & 0.5671 & -0.0362 & 0.9033 & 0.1319 & -0.6086 & 0.2080 & 0.0 \\
\hline & & 25 & 0.5677 & 0.0300 & 0.8811 & 0.1221 & -0.5503 & 0.1022 & 0.0 \\
\hline & 15 & 2 & 0.5722 & -0.5863 & 0.9638 & 0.1783 & -0.8673 & 0.9948 & 0.6 \\
\hline & & 4 & 0.5763 & -0.1144 & 0.8916 & 0,1264 & -0.6422 & 0.4785 & 0.0 \\
\hline & & 6 & 0.5770 & -0.0802 & 0.8884 & 0.1134 & -0.5752 & 0.3226 & 0.0 \\
\hline & & 25 & 0.5794 & 0.0633 & 0.8582 & 0.0970 & -0.5053 & 0.2016 & 0.0 \\
\hline & 45 & 2 & 0.5907 & 0.0386 & 0.8674 & 0.0981 & -0.5201 & 0.3546 & 0.0 \\
\hline & & 4 & 0.5926 & 0.2128 & 0.8109 & 0.0697 & -0.4183 & 0.2321 & 0.0 \\
\hline & & 6 & 0.5924 & 0.2422 & 0.8116 & 0.0630 & -0.3655 & 0.1783 & 0.0 \\
\hline & & 25 & 0.5935 & 0,3118 & 0,7801 & 0,0542 & -0.3344 & 0.1504 & 0.0 \\
\hline & 90 & 2 & 0.5959 & 0.1291 & 0.8210 & 0.0686 & -0.3849 & 0.2385 & 0.0 \\
\hline & & 4 & 0.5965 & 0.3444 & 0.7675 & 0.0488 & -0.2883 & 0.1127 & 0.0 \\
\hline & & 6 & 0,5963 & 0.3294 & 0.7490 & 0.0442 & -0.2632 & 0.0852 & 00 \\
\hline & & 25 & 0.5966 & 0,4011 & 0.7425 & 0.0379 & -0.2364 & 0.0747 & 0,0 \\
\hline \multirow[t]{24}{*}{0.90} & 2 & 2 & 0.5795 & -0.9999 & 1.0000 & 0.5620 & -1.5561 & 1.2209 & 16.0 \\
\hline & & 6 & 0.6473 & -0.2000 & 0.9989 & 0.3627 & -1.0781 & -0.1640 & 10,3 \\
\hline & & 10 & 0.6601 & -0.1111 & 0.9965 & 0.3383 & $-1,0309$ & -0.2751 & 8.3 \\
\hline & & 25 & 0.6672 & -0.0417 & 0.9954 & 0.3196 & -0.9688 & -0.4152 & 5.4 \\
\hline & 5 & 2 & 0.8408 & .0 .9534 & 0.9994 & 0.1753 & -3.0649 & 13.7740 & 0.7 \\
\hline & & 6 & 0.8452 & -0.1883 & 0,9903 & 0,1298 & -2.3956 & 7.9583 & 0.1 \\
\hline & & 10 & 0.8467 & -0.0946 & 0.9890 & 0.1231 & -2.2809 & 7.1051 & 0.0 \\
\hline & & 25 & 0.8475 & -0.0331 & 0.9869 & 0.1176 & -2.2402 & 6.8771 & 0.0 \\
\hline & 10 & 2 & 0.8773 & -0.2971 & 0.9984 & 0.0858 & -2.2838 & 96368 & 0.0 \\
\hline & & 6 & 0.8786 & 0,1748 & 0.9821 & 0.0646 & -1.9004 & 6.1650 & 0.0 \\
\hline & & 10 & 0.8787 & 0.1120 & 0.9846 & 0.0618 & -1.8720 & 6.1793 & 0.0 \\
\hline & & 25 & 0.8795 & 0.1713 & 0.9798 & 0.0589 & -1.8341 & 6.1174 & 0.0 \\
\hline & 15 & 2 & 0,8865 & 0.0783 & 0.9916 & 0.0612 & $-1,7244$ & 5,7989 & 0.0 \\
\hline & & 4 & 0,8870 & 0.4350 & 0.9779 & 0.0492 & -1.5305 & 4.2894 & 0.0 \\
\hline & & 6 & 0.8870 & 0,4356 & 0.9774 & 0.0463 & -1.4622 & 3.8131 & 0.0 \\
\hline & & 25 & 0.8874 & 0.4326 & 0.9737 & 0.0425 & -1.4024 & 3.5535 & 0.0 \\
\hline & 45 & 2 & 0.8959 & 0.6393 & 0.9738 & 0.0304 & -0.8492 & 1.2862 & 0.0 \\
\hline & & 4 & 0.8961 & 0.7316 & 0.9601 & 0.0242 & -0.7732 & 1.0780 & 0.0 \\
\hline & & 6 & 0,8962 & 0.7435 & 0.9582 & 0.0227 & -0.7706 & 1.0583 & 0.0 \\
\hline & & 25 & 0.8962 & 0.7231 & 0.9522 & 0.0210 & -0.7631 & 1,1282 & 00 \\
\hline & 90 & 2 & 0.8979 & 0.7779 & 0.9596 & 0.0208 & -0.5832 & 0.5936 & 0.0 \\
\hline & & 4 & 0.8981 & 0.7606 & 0,9492 & 0.0165 & -0.5496 & 0.5814 & 0.0 \\
\hline & & 6 & 0.8981 & 0.7976 & 0.9429 & 0,0155 & -0.5312 & 0.4924 & 00 \\
\hline & & 25 & 0.8982 & 0.7882 & 0.9483 & 0.0143 & -0.5275 & 0.5258 & 0.0 \\
\hline
\end{tabular}


Şekil 1. $p=0.00$ için çeşitli grup ve örnek genişliği kombinasyonlarına göre hesaplanan grup içi korelasyon katsayılarının dağılımı

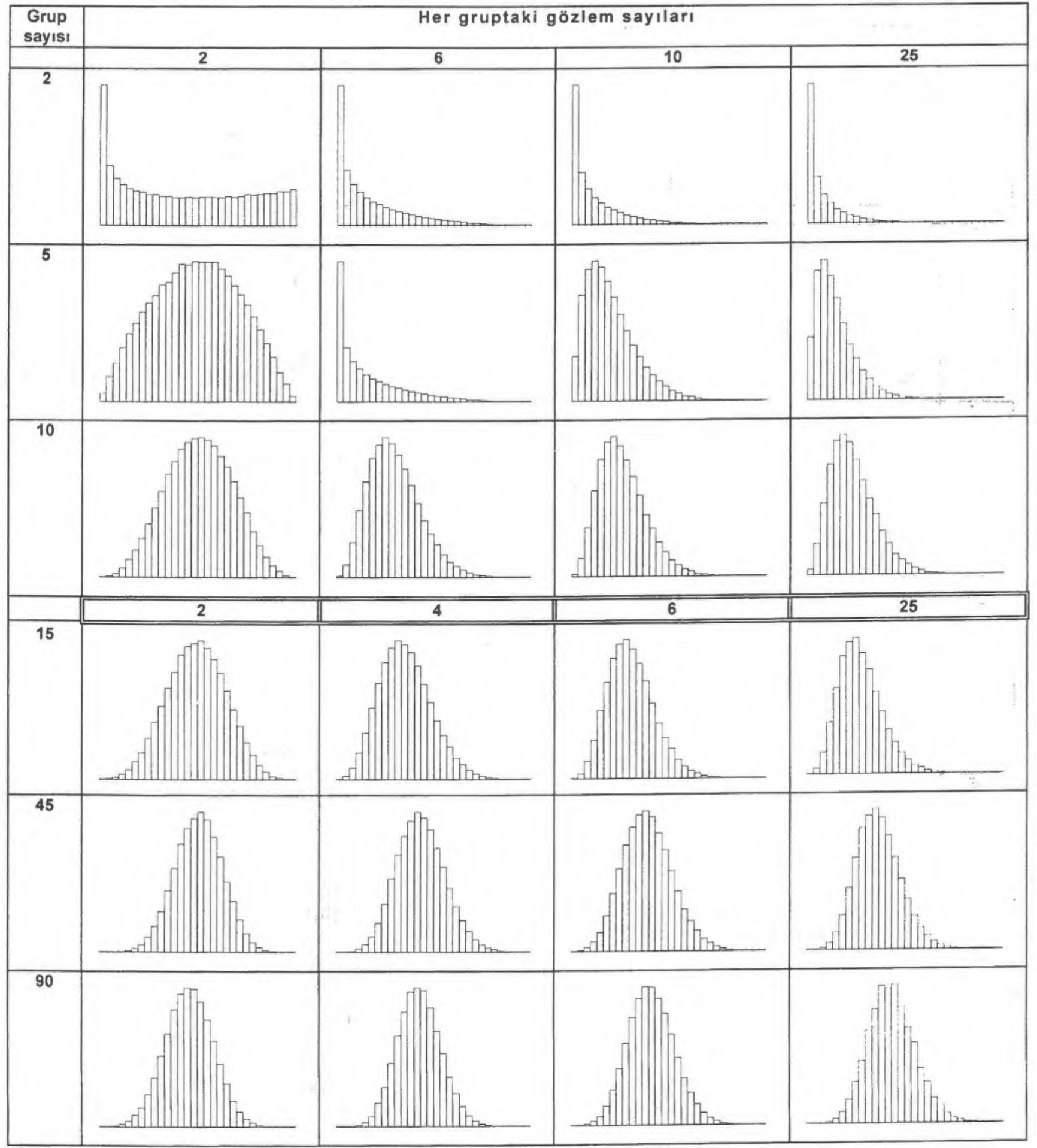


Şekil 2. $\rho=0.30$ için çeşitli grup ve örnek genişliği kombinasyonlarına göre hesaplanan grup içi korelasyon katsayılarının dağıımı

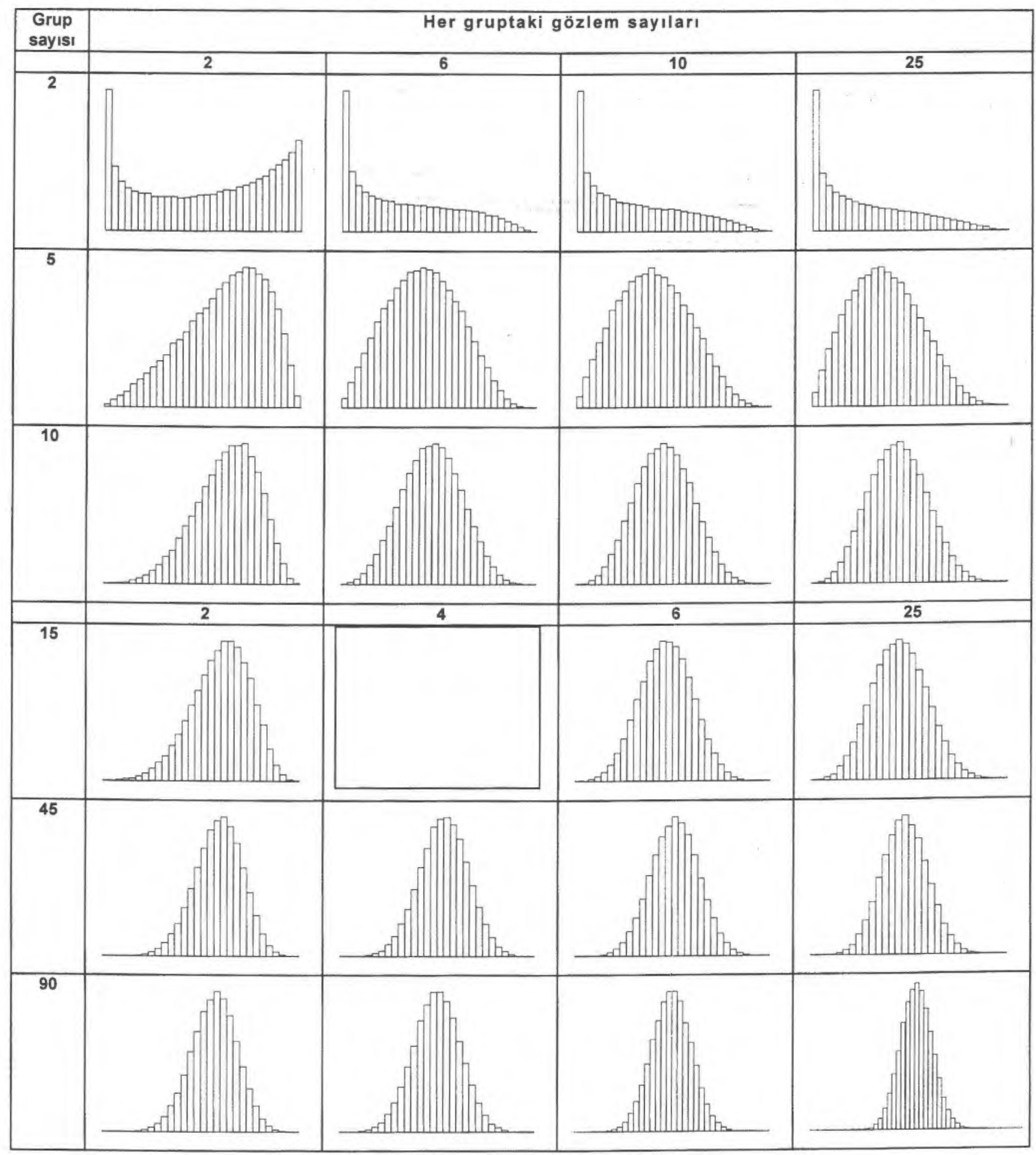


Şekil 3. $\rho=0.60$ için çeşitli grup ve örnek genişliği kombinasyonlarına göre hesaplanan grup içi korelasyon katsayılarının dağııımı

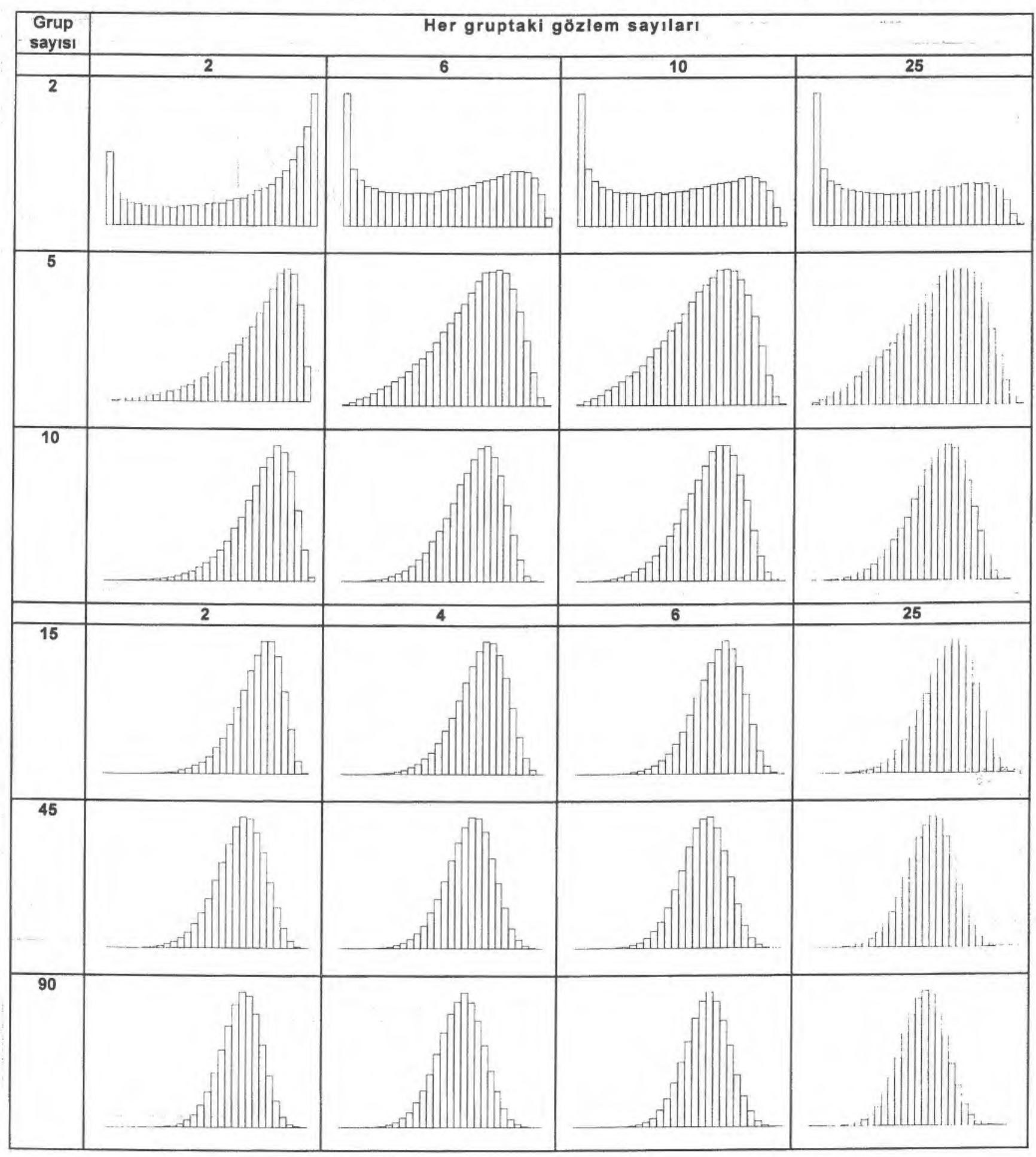


Şekil 4. $p=0.90$ için çeşitli grup ve örnek genişliği kombinasyonlarına göre hesaplanan grup içi korelasyon katsayılarının dağıımı

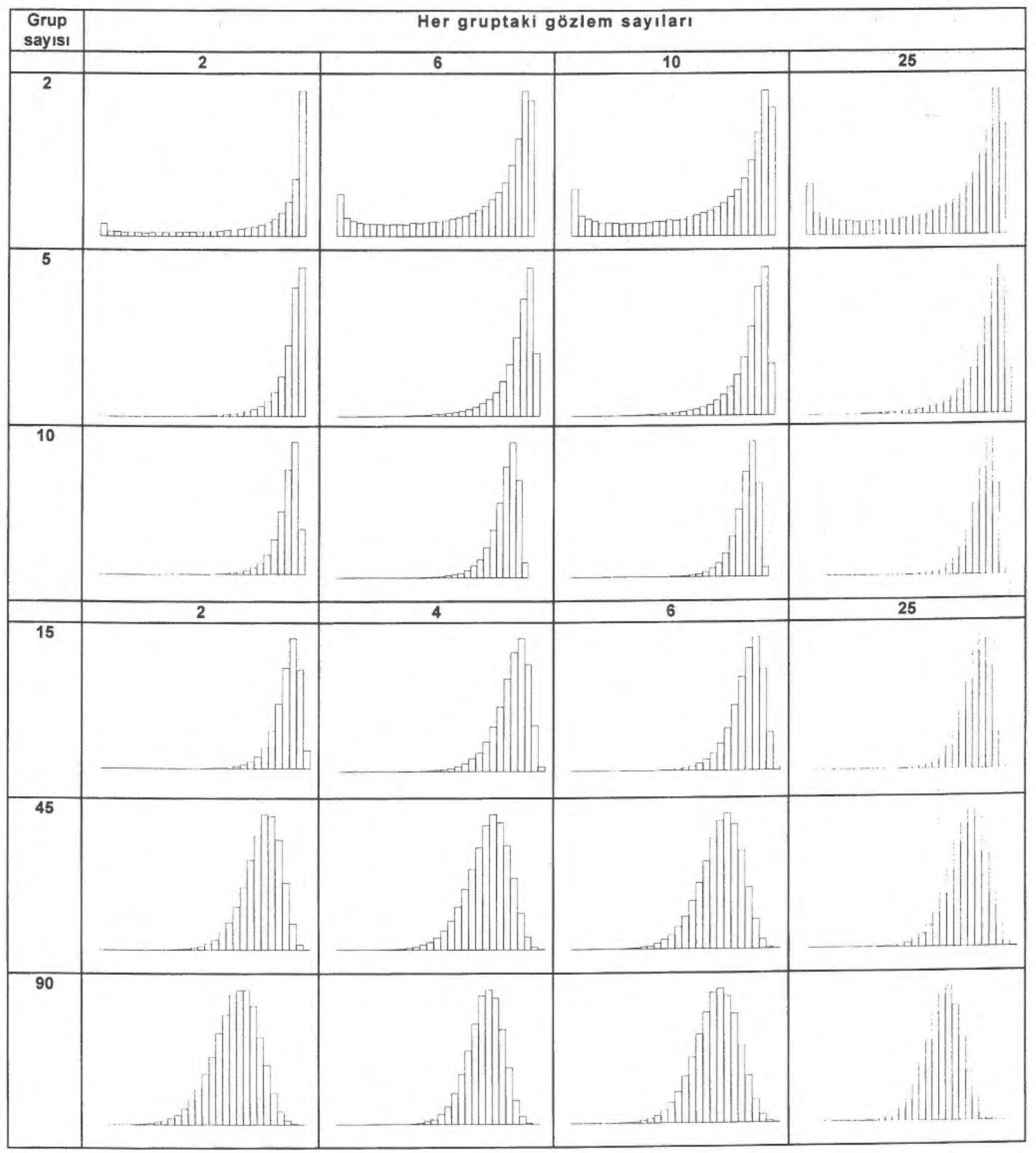


Çizelge '2' nin $\rho_{i j}=0.90 \mathrm{kısmı} \mathrm{ile} \mathrm{Şekil} 4$ 'ün birlikte incelenmesi ile, grup sayısının 2-5 arasında olmasi halinde, gruplardaki gözlem sayılarına göre değişen oranlarda, hesaplanan grup içi korelasyon katsayılarının arasında negatif değerlere rastlanılabileceği górülmektedir. $\rho=0.90$ olduğu populasyondan rasgele alinan örneklerde $100 \quad 000$ simülasyon sonunda elde edilen grup içi korelasyon katsayilarinin gösterdiği dağılımin sekil olarak, $p=0.00$ olan populasyon için hesaplanan grup içi korelasyonlanın dağılım şekillerinin tam zıttı olacak şekilde, yani 0.90 civarında bir yığilma ve 0.90 dan küçük degerli grup içi korelasyonlanın frekanslarinda azalma olduğu görülmektedir. Grup ve her gruptaki gözlem sayısından bağımsız olarak, grup içi korelasyon katsayısının örnekleme dağılımının gittikçe simetriklikten ayrildığı ve dağılımın daima sola yatık olduğu Şekil 4 ten görülmektedir. Önekleme dağılimının normal dağılıma yaklaşmasının asimtotik olarak da pek mümkün olmadıği Çizelge 2'nin incelenmesinden anlaşılmaktadir $\rho=0.90$ olan bir populasyondan rasgele alınan örneklerden hesaplanan grup içi korelasyon katsayısı, grup sayısı 15 ve daha fazla ve her gruptaki gözlem sayisinin da en az 2 olmasi halinde anlami değerler almaktadır. Çünko, bu durumda grup içi korelasyon katsayısı ortalama olarak p'ya yaklaşmakta ve pozitif değerier aimaktadır.

Çizelge 2 ve Şekil 1,2,3,4 genel olarak değerlendirildiğinde, grup arası (inter-class $=\rho_{i j}$ ) yani her bir gruptaki gözlemler arası korelasyon katsayısı sıfir olduğunda, hesaplanan grup içi korelasyon katsayisi, $\mathrm{kj}_{j}$ ve $n_{i}$ teorik olarak $\propto$ olduğunda sıfir olarak gerçekleşmekte ve böyle populasyondan rasgele alinan orneklerden hesaplanan grup içi korelasyon katsayısının örnekleme dağılımı normal dağılım göstermemektedir. Benzer durum, $\rho_{\mathrm{ij}}=0,30,0.60$ ve 0.90 olması halinde de görülmektedir. Bu durumda her hangi bir örnekte hesaplanan grup içi korelasyon katsayısının ( $\left.r_{i}\right)$ önemlilik testinin nasıl yapılacağı gündeme gelmektedir. Bunun için klasik olarak, 3 farki yaklaşım kullanımaktadir. Bunlar sırasıyla, varyans analizi tekniği sonunda yapılan $F$-testi, grup içi korelasyonların $Z$-dönüşümü sonucu t-testi ve güven aralığıdır. Bu test tekniklerinin tamamı, normal dağıım on şartın gerektirmektedir. Halbuki grup içi korelasyon katsayısının asimtotik olarak bile normal dağılmadığı, çeşitli korelasyon yapılarındaki populasyonlar için bu çalışmada gösterilmiştir. Benzer sonuçlar çeşitli araştırıcilarca da bildirilmektedir (Paul 1996. Kromrey ve Dickinson 1996, Kurita 1996, Bond 1997).

Söz konusu önemlilik testinin yapılabilmesi, ancak grup içi korelasyon katsayısının dağılım fonksiyonunun belirlenmesi ile mümkün olabileceği gibi, belirlenmiş bir $\alpha$ ıçin simülasyon sonunda, $\alpha$ 'nın başladığı değerin tespit edilmesi de hipotez kontrolünde bir yaklașimdır. Boyle bir çalışma planlanmış ve yürütülme aşamasındadı. Grup içi korelasyon katsayisi özelikje isłah çalıșmalarinda, kalitım derecesinin tahmin edilmesinde onemli bit kriter olduğundan böyle bir yaklaşıma intiyaç duyulmaktadır.

\section{Sonuç}

Bu çalışmada, grup içi korelasyon katsayısının ömekleme dağılımının nasıl olduğu ele alınmıştır. Bunun için çeşitli grup arasi korelasyona sahip, populasyonlar simülasyon tekniĝi ile üretilmiş ve bu populasyonlardan alınan çeşitli örnek genişliğindeki örnekler kullanılarak, her örnekte grup içi korelasyon katsayısı hesaplanmıştır. Bu şekilde 100000 deneme sonunda hesaplanan grup içi korelasyon katsayılarının örnekleme dağılımları belirienmeye çalışıımıştır. Yapilan simülasyon denemeleri sonunda, hesaplanan grup içi korelasyon katsayısının örnekleme dağılımının $\rho=0.00$ olması halinde bile, normal dag̣ılım olmadığı, dağılım șekli olarak, populasyondaki grup arası korelasyon katsayısı, grup ve her gruptaki gözlem sayısına bağı olarak normal dağılim dışında oldukça değişik dağilımlar gösterdiği sonucuna varılmıştır.

\section{Kaynaklar}

Bond, M E 1997. Using Prior Knowledge of Intraclass Correlation to Increase the Power of Hypothesis Tests for Treatment Means. DAl-Bi (57) 07.4497 s

Dìzgüneș, O. A. Eliçin, N. Akman, 1987 Hayvan Islahı Ankara Universitesi Ziraat Fakültesi Yayınlar!: 1003.298 S

Fisher, R, A. 1958. Statistical Methods for Research Warkers. Hafner Publihing Co.Inc. New York, 212-247 s.

Kromrey, J. D. ve W. B. Dickinson, 1996. Detecting Unit of Analysis Problems in Nested Designs-Statistical Power and Type-t Error Rates of the F-Test for Groups-WithinTreatments Effects. Educational and Psychological Measurement, (56) 2, 215-231 s.

Kurita, K. 1996. The Biasing Effects of Violating the independence Assumption Upan the Power of t-Test. Jap. Jour of Educational Psychology, (44) 2, 234-242 s.

Paul, S. R. 1996. Score Test for Interclass Correlation in Familial Data. Biometrics, (56) $3,955-963 \mathrm{~s}$

Rosner. B. 1979. Maximum Likelihood Estimation of Inierclass Correlations. Biometrica, (66) 3, 533-538 s

Sokal, R. R. ve F, J. Rohit, 1995. Biometry. The Principles and Practice of Statistics in Biological Research. Third Ed W.H. Freeman and Co. New York. $887 \mathrm{~s}$.

Tumer, H. N ve S. S Y Young, 1969. Quantitative Genetics in Sheep Breeding, Comell University Press. Ithaca, New York. $332 \mathrm{~s}$

Winer, B. J. 1971. Statistical Principles in Experimental Design. Second Ed. McGraw-Hill Book Co. New York 907 s. 